\title{
Technology Foresight Research on China's Environmental Engineering Science and Technology to 2035
}

\author{
Dan Zhigang ${ }^{1}$, Shi Feifei ${ }^{1}$, Wang Zhizeng ${ }^{2}$, Wang Huifeng ${ }^{1}$, Zhang Peilei ${ }^{1,3}$, Hao Jiming ${ }^{3}$, Duan Ning ${ }^{1}$ \\ 1. Technology Center for Heavy Metal Cleaner Production Engineering, Chinese Research Academy of Environmental Sciences, Beijing 100012, China \\ 2. Research Institute of Forest Ecology, Environment and Protection, Chinese Academy of Forestry, Beijing 100091, China \\ 3. School of Environment, Tsinghua University, Beijing 100084, China
}

\begin{abstract}
The Delphi method is the most commonly used method in technology foresight, which is a significant basis for establishing development strategies as well as policies for science and technology. This study proposes 45 alternative technologies in the field of environmental engineering science and technology through a literature survey, expert advice, and discussion meetings. These technologies relate to air pollution prevention and control; water pollution prevention and control; soil pollution prevention and control; solid waste pollution prevention, control, and utilization; ecological protection and restoration; environmental monitoring, early warning, and risk control; and resource utilization and cleaner production. Based on the results obtained using the Delphi method, this research analyzes the realization time; R\&D level; and restriction factors for the key, common, and disruptive technologies determined for 2035. This study will provide a reference for establishing development strategies and objectives for China's environmental engineering science and technology over the next 20 years.
\end{abstract}

Keywords: environmental engineering science and technology; technology foresight; Delphi method; key technology; common technology; disruptive technology

\section{Introduction}

Technology foresight evaluates and forecasts the strategic focus areas and key fields in the development of science and technology using scientific methods and analyses [1-3]. Since the 1990s, science and technology has played a prominent role in economic development. Against this background, technology foresight has been adopted as an important aspect in formulating policies and establishing the development strategy of science and technology worldwide. Methods of technology foresight include the Delphi method, expert meetings, trend analysis, scenario analysis, and other research methods [4]. The Delphi method, an expert-established investigation method, is a means of collecting expert opinions without having to engage in faceto-face interactions and is a highly efficient method for solving complicated problems through group communication [5]. This method is widely used across the world in developing medium and long-term strategies in the field of science and technology.

With rapid economic growth in China, environmental issues have cropped up and are now playing an increasingly significant role in restricting China's further economic development. Environmental engineering science and technology is the key to resolving environmental issues. Accurately and scientifically grasping the field of environmental science and technology is of importance to the next 20 years, which mark a critical period in China's economic and social development. Supported by the

Received date: 9 December 2016; revised date: 20 December 2016

Corresponding author: Dan Zhigang, Technology Center for Heavy Metal Cleaner Production Engineering, Chinese Research Academy of Environmental Sciences, Professor. Major research field is the theory, methods, and policies of cleaner production. E-mail: dash_2001@163.com

Funding program: CAE Advisory Project “Research on China's Engineering Science and Technology Development Strategy 2035” (2015-ZD-14)

Chinese version: Strategic Study of CAE 2017, 19 (1): 080-086

Cited item: Dan Zhigang et al. Technology Foresight Research on China's Environmental Engineering Science and Technology to 2035. Strategic Study of CAE, https:// doi.org/10.15302/J-SSCAE-2017.01.012 
"Research on China's Engineering Science and Technology Development Strategy 2035" project, this study proposes key, common, and disruptive technologies, which are determined using the Delphi method, and analyzes the realization time, R\&D lev$\mathrm{el}$, and restriction factors. It contributes to the choices that will be made during the development of ideas for future technologies in the field of environmental engineering science and technology in China.

\section{Methods and processes of technology foresight}

\subsection{Delphi method}

\subsubsection{Investigation items}

The Delphi questionnaire of "Research on China's Engineering Science and Technology Development Strategy 2035" (Table 1) contains nine columns with 53 options, including the extent of familiarity, importance of technology itself, importance of technology application, current R\&D level in China, technological leaders, technology realization time (worldwide), technology realization time (in China), social realization time (in China), and restriction factors (multiple options). Here, the importance of technology itself is analyzed using four factors - the pivotal role it plays, its universality, its driving ability, and discontinuitywhile the importance of technology application is analyzed using three factors - economic development, social development, and national defense and state security.

The questionnaire classifies the extent of the expert's familiarity under the following categories: quite familiar, familiar, relatively familiar, and unfamiliar. In the case of data analysis, a different weight is given according to the extent of familiarity.

\subsubsection{Analysis indicators}

To screen the key, common, and disruptive technologies, we constructed the corresponding key, common, and disruptive technology indexes according to seven factors, technology itself importance, and technology application importance. The relation schema of the importance indexes is shown in Fig. 1.

Based on the importance of this technology's impact on the economy, society, and national defense and state security, these three indexes show different emphases. The key technology index emphasizes the core and driving ability of this technology; the common technology index stresses the wide application scope; and the disruptive technology index focuses on the substitution of the current mainstream technology.

\subsection{Determination of alternative technologies}

\subsubsection{Division of subfields}

Environmental engineering science and technology covers an extensive range and vastly different specialties. Based on the "Research on China's Engineering Science and Technology Development Strategy 2030," with reference to Japan's 10th Science and Technology Foresight and technical classification of "China's Technology Foresight in the Next 20 Years" under the Ministry of Science and Technology of the People's Republic of China, this study sets seven subfields for the field of environmental engineering science and technology: air pollution prevention and control; water pollution prevention and control; solid waste pollution prevention, control, and utilization; soil pollution prevention and control; ecological protection and restoration; environmental monitoring, early warning, and risk control; and resource utilization and cleaner production.

\subsubsection{Determination of alternative technologies}

In line with the demand for national economic and social development in the field of environmental engineering science and technology and the vision of future engineering, this survey

Table 1. Delphi questionnaire on technology foresight research.

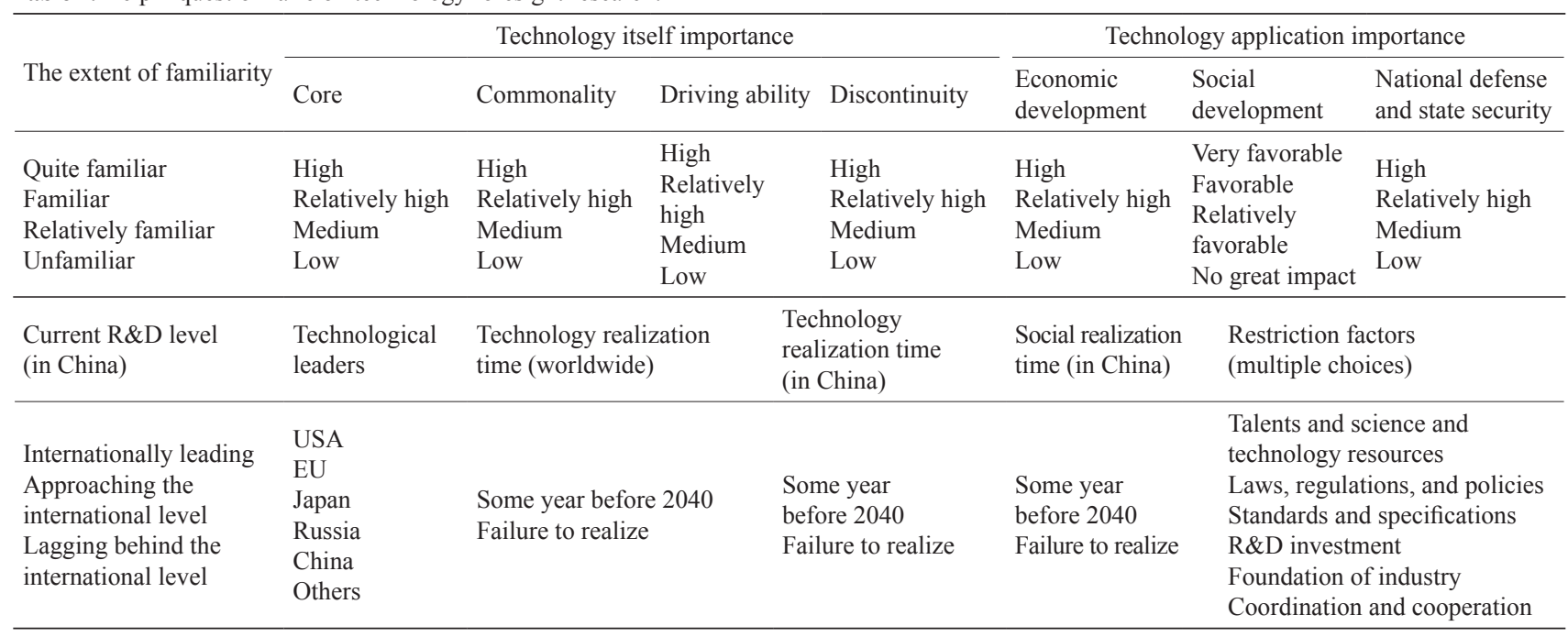


proposes 45 alternative technologies through expert advice and discussion meetings. The distribution of technology in each subfield is shown in Fig. 2.

\subsection{Outline of the Delphi survey}

To ensure the scientificity and accuracy of technology foresight, this study conducted two rounds of the Delphi survey on alternative technologies in this field. Table 2 gives basic details of the second survey. On average, 30 questionnaires were collected for the survey on each technology; therefore, from a statistical perspective, this investigation is of significance.

Fig. 3(a) shows the distribution of experts participating in the survey: it can be seen that those from university and research institutions account for $71.4 \%$ of all participating experts; the level of participation from enterprises is low, with only $10.4 \%$ of the invited respondents from enterprises filling in the questionnaire. With regard to the experts' familiarity with technologies, as shown in Fig. 3(b), 56.2\% of the experts indicated that they were "quite familiar" or "familiar" with the related technology items; $42.8 \%$ of them indicated that they were "relatively familiar." On the whole, the survey results are superior in terms of both professionality and statistical significance.

\section{Results on survey of technology foresight of environmental engineering science and technology}

\subsection{General}

The importance index scores of alternative technologies in

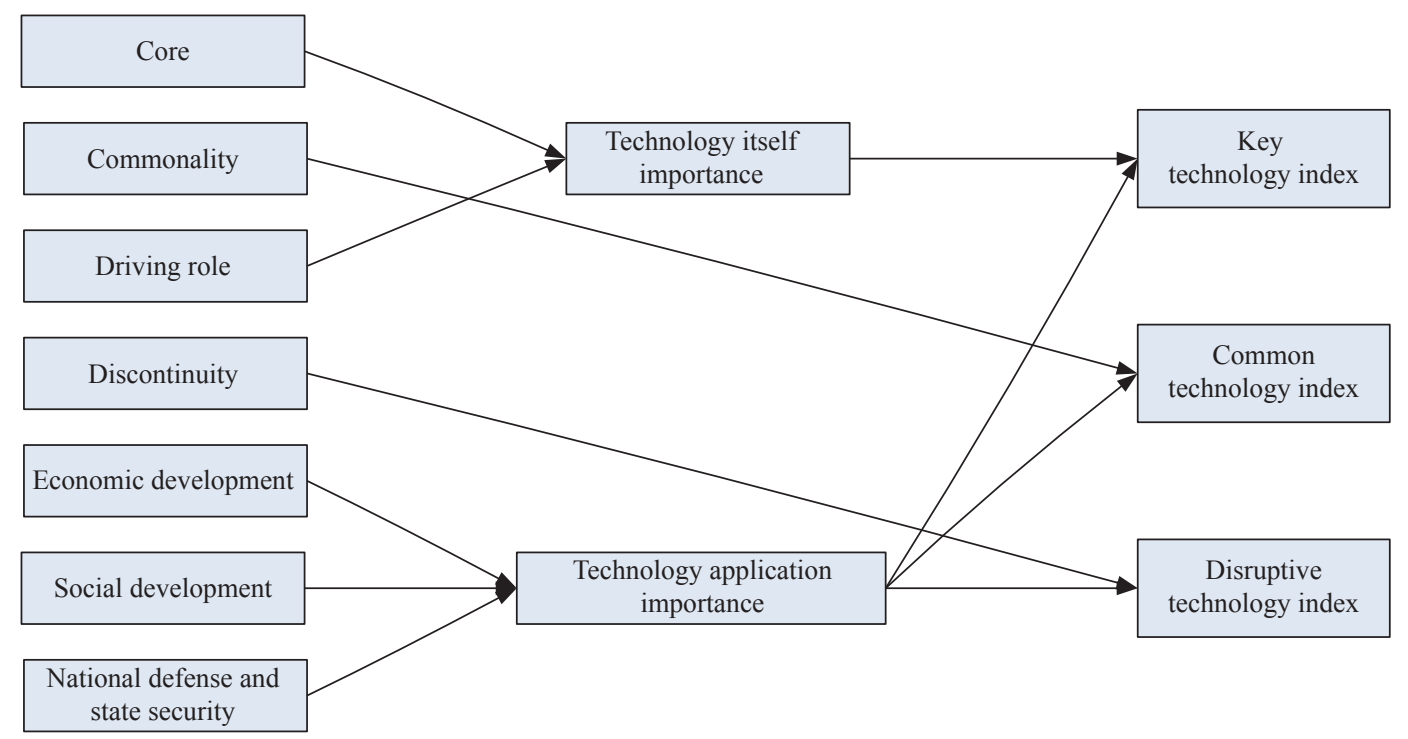

Fig. 1. Relation schema of the importance indexes.

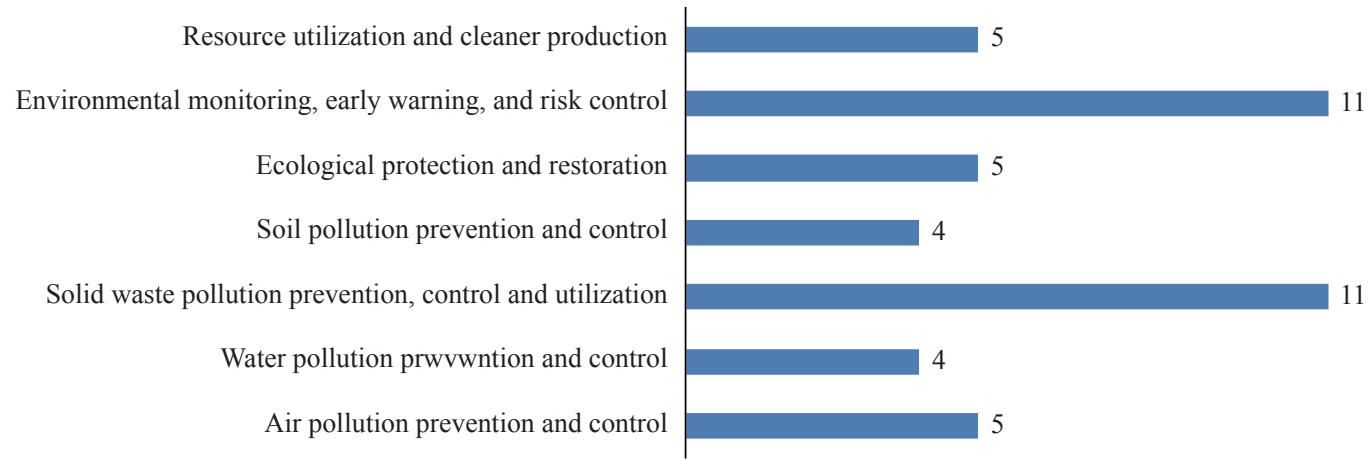

Fig. 2. Distribution of technology items in various subfields.

Table 2. Basic information of the second Delphi survey on environmental engineering science and technology.

\begin{tabular}{cccccc}
\hline Subfields & $\begin{array}{c}\text { Number of technology } \\
\text { items }\end{array}$ & $\begin{array}{c}\text { Number of invited } \\
\text { people }\end{array}$ & $\begin{array}{c}\text { Number of respondents who } \\
\text { filled in the questionnaire }\end{array}$ & $\begin{array}{c}\text { Total number of } \\
\text { questionnaires }\end{array}$ & $\begin{array}{c}\text { Average number of } \\
\text { questionnaires }\end{array}$ \\
\hline 7 & 45 & 921 & 220 & 1350 & 30 \\
\hline
\end{tabular}




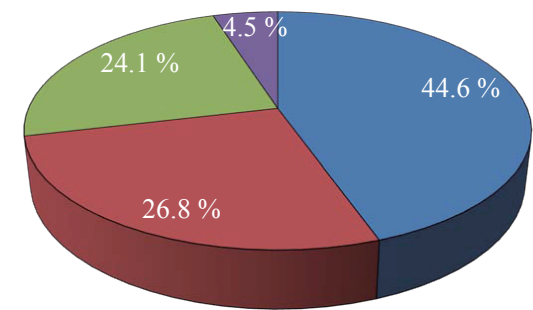

$\square$ University

$\square$ Research institutions

$\square$ Enterprises and public institutions

(a)

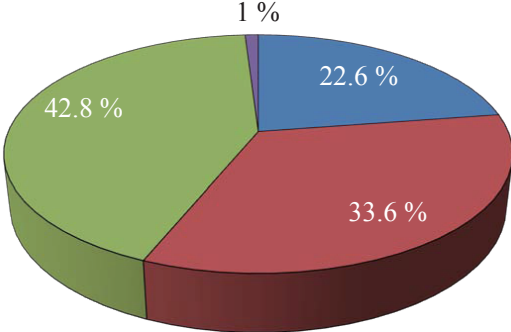

$\square$ Quite familiar

口Familiar

$\square$ Relatively familiar

(b)

Fig. 3. Analysis of Delphi survey on environmental engineering science and technology. (a) Distribution of the participating experts' affiliated organizations; (b) Distribution of the experts' familiarity with technologies.

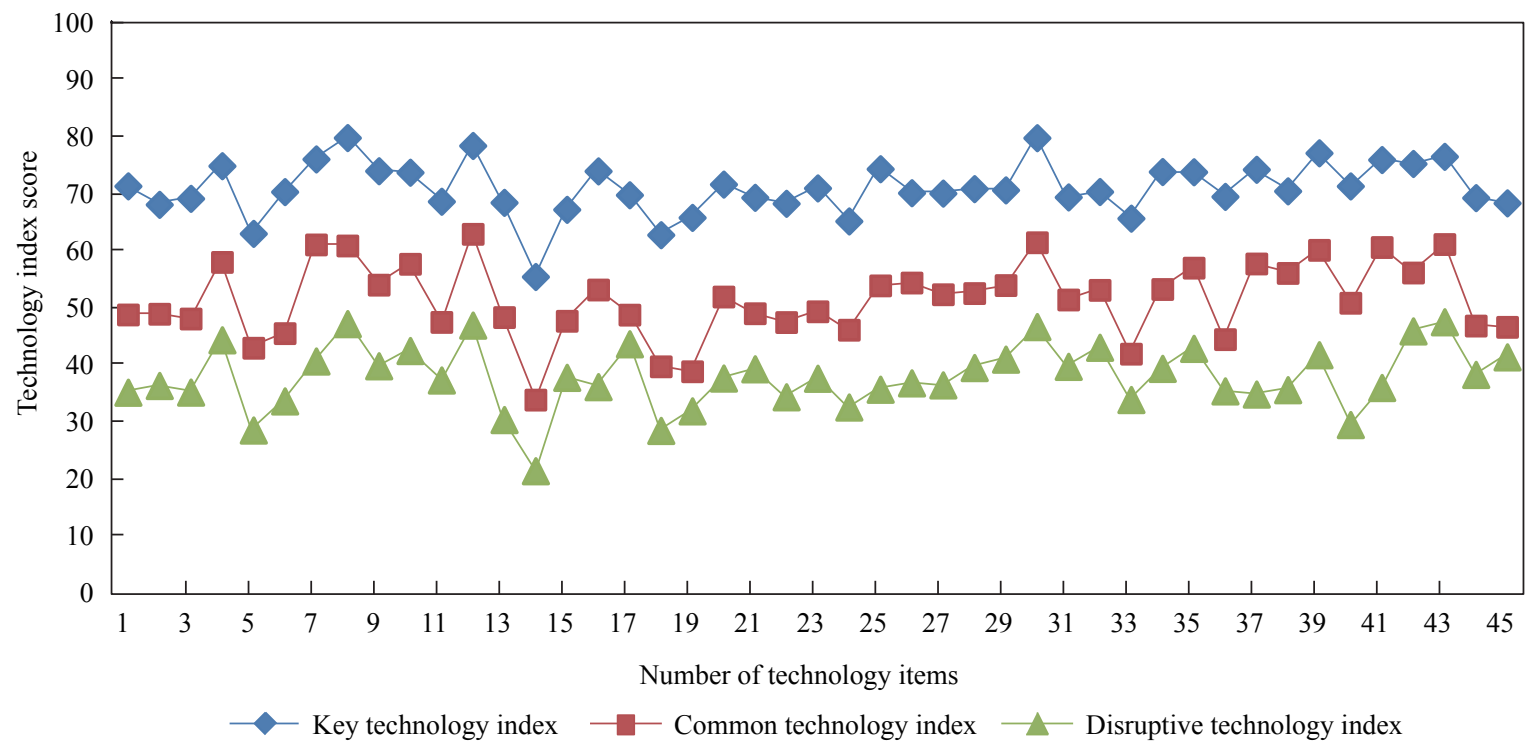

Fig. 4. Importance index scores of alternative technologies in the field of environmental engineering science and technology.

the field of environmental engineering science and technology are shown in Fig. 4. The key, common, and disruptive technology indexes among the alternative technologies are, on average, $71.0,51.5$, and 37.8 , respectively. As a whole, these alternative technologies have a better importance index on average, indicating that the screened technologies are typical and can better reflect the key direction of environmental engineering science and technology.

\subsection{Key, common, and disruptive technologies of environmental engineering science and technology}

Table 3 shows the top-10 key, common, and disruptive technologies in the field of environmental engineering science and technology, according to the Delphi method. The indexes of the top-10 key technologies are all above 74 , in which "micropollution prevention and control, and safe utilization technology of underground water and drinking water" has the highest index at 79.85. "System management technology of basin pollution control" has the highest index among the common technologies at 62.97. "Substitution of poisonous and harmful raw materials and catalysts in the chemical production process" has the highest index among the disruptive technologies at 47.55.

\subsection{Technology development level and restriction factors}

As a whole, the environmental engineering field has a relatively low level of R\&D in technology (Fig. 5), with $95.6 \%$ of the technologies being underdeveloped or greatly lagging behind the global level. In this field, the "compact processing and molding technology of energy-efficient polymer products" represents the highest R\&D level with an index of 47.5, whereas "environmental emergency monitoring, handling, and disposal technology and equipment" has the lowest R\&D-level index of 7.14. The 
EU and the USA, leaders in this field, enjoy higher R\&D-level indexes in all technologies. The USA has absolute advantages in the four subfields of air pollution prevention and control; soil pollution prevention and control; ecological protection and restoration; and environmental monitoring, early warning, and risk control. The EU is ahead of the USA, China, Japan, and Russia in three subfields: water pollution prevention and control; solid waste pollution prevention, control, and utilization; and resource utilization and cleaner production. The distribution of the technological leaders in this field is shown in Fig. 6 (the horizontal axis in Fig. 6 corresponds to the seven subfields from top to bottom, respectively, shown in Fig. 2).

Overall, the primary factor that restricts the development of environmental engineering science and technology is inadequate $\mathrm{R} \& \mathrm{D}$ investment, followed by dearth of talents and science and technology resources. Coordination and cooperation have little

Table 3. Top-10 key, common, and disruptive technologies of environmental engineering science and technology.

\begin{tabular}{|c|c|c|c|}
\hline No. & Key technologies & Common technologies & Disruptive technologies \\
\hline 1 & $\begin{array}{l}\text { Micro-pollution prevention and control, and } \\
\text { safe utilization technology of underground } \\
\text { water and drinking water }\end{array}$ & $\begin{array}{l}\text { System management technology of basin } \\
\text { pollution control }\end{array}$ & $\begin{array}{l}\text { Substitution of poisonous and harmful raw } \\
\text { materials and catalysts in the chemical } \\
\text { production process }\end{array}$ \\
\hline 2 & $\begin{array}{l}\text { Restoration and improvement technology of } \\
\text { the ecosystem function in the ecologically } \\
\text { vulnerable area }\end{array}$ & $\begin{array}{l}\text { Restoration and improvement technology of } \\
\text { the ecosystem function in the ecologically } \\
\text { vulnerable area }\end{array}$ & $\begin{array}{l}\text { Micro-pollution prevention and control, and } \\
\text { safe utilization technology of underground } \\
\text { water and drinking water }\end{array}$ \\
\hline 3 & $\begin{array}{l}\text { System management technology of basin } \\
\text { pollution control }\end{array}$ & $\begin{array}{l}\text { Substitution of poisonous and harmful raw } \\
\text { materials and catalysts in the chemical } \\
\text { production process }\end{array}$ & $\begin{array}{l}\text { System management technology of basin } \\
\text { pollution control }\end{array}$ \\
\hline 4 & $\begin{array}{l}\text { Comprehensive 3D monitoring/telemetry } \\
\text { technology of environmental quality }\end{array}$ & $\begin{array}{l}\text { Drinking water quality safety assurance and } \\
\text { risk control technology from the source to the } \\
\text { faucet }\end{array}$ & $\begin{array}{l}\text { Restoration and improvement technology of } \\
\text { the ecosystem function in the ecologically } \\
\text { vulnerable area }\end{array}$ \\
\hline 5 & $\begin{array}{l}\text { Substitution of poisonous and harmful raw } \\
\text { materials and catalysts in the chemical } \\
\text { production process }\end{array}$ & $\begin{array}{l}\text { Micro-pollution prevention and control, and } \\
\text { safe utilization technology of underground } \\
\text { water and drinking water }\end{array}$ & $\begin{array}{l}\text { Harmless treatment by smelting waste } \\
\text { containing heavy metal with the wet process, } \\
\text { and resource utilization technology }\end{array}$ \\
\hline 6 & $\begin{array}{l}\text { Drinking water quality safety assurance and } \\
\text { risk control technology from the source to the } \\
\text { faucet }\end{array}$ & $\begin{array}{l}\text { Compact processing and molding technology } \\
\text { of energy-efficient polymer products }\end{array}$ & $\begin{array}{l}\text { Motor vehicle pollution control technology } \\
\text { and equipment }\end{array}$ \\
\hline 7 & $\begin{array}{l}\text { Compact processing and molding technology } \\
\text { of energy-efficient polymer products }\end{array}$ & $\begin{array}{l}\text { Comprehensive 3D monitoring/telemetry } \\
\text { technology of environmental quality }\end{array}$ & $\begin{array}{l}\text { Treatment and disposal technology of } \\
\text { radioactive waste }\end{array}$ \\
\hline 8 & $\begin{array}{l}\text { Harmless treatment by smelting waste } \\
\text { containing heavy metal with the wet process, } \\
\text { and resource utilization technology }\end{array}$ & $\begin{array}{l}\text { Motor vehicle pollution control technology } \\
\text { and equipment }\end{array}$ & $\begin{array}{l}\text { Basic information system of water ecological } \\
\text { restoration plus an Internet platform }\end{array}$ \\
\hline 9 & $\begin{array}{l}\text { Motor vehicle pollution control technology } \\
\text { and equipment }\end{array}$ & $\begin{array}{l}\text { High-quality/multi-functional/integrated/ } \\
\text { intelligent/Internet-based environmental } \\
\text { monitoring sensor }\end{array}$ & $\begin{array}{l}\text { Ecological protection and restoration } \\
\text { technology of major transportation } \\
\text { infrastructure construction }\end{array}$ \\
\hline 10 & $\begin{array}{l}\text { Packaged technology and equipment of } \\
\text { polluted site remediation and control }\end{array}$ & $\begin{array}{l}\text { Key technology of industrial wastewater } \\
\text { desalination and water reuse }\end{array}$ & $\begin{array}{l}\text { Key technology of industrial wastewater } \\
\text { desalination and water reuse }\end{array}$ \\
\hline
\end{tabular}

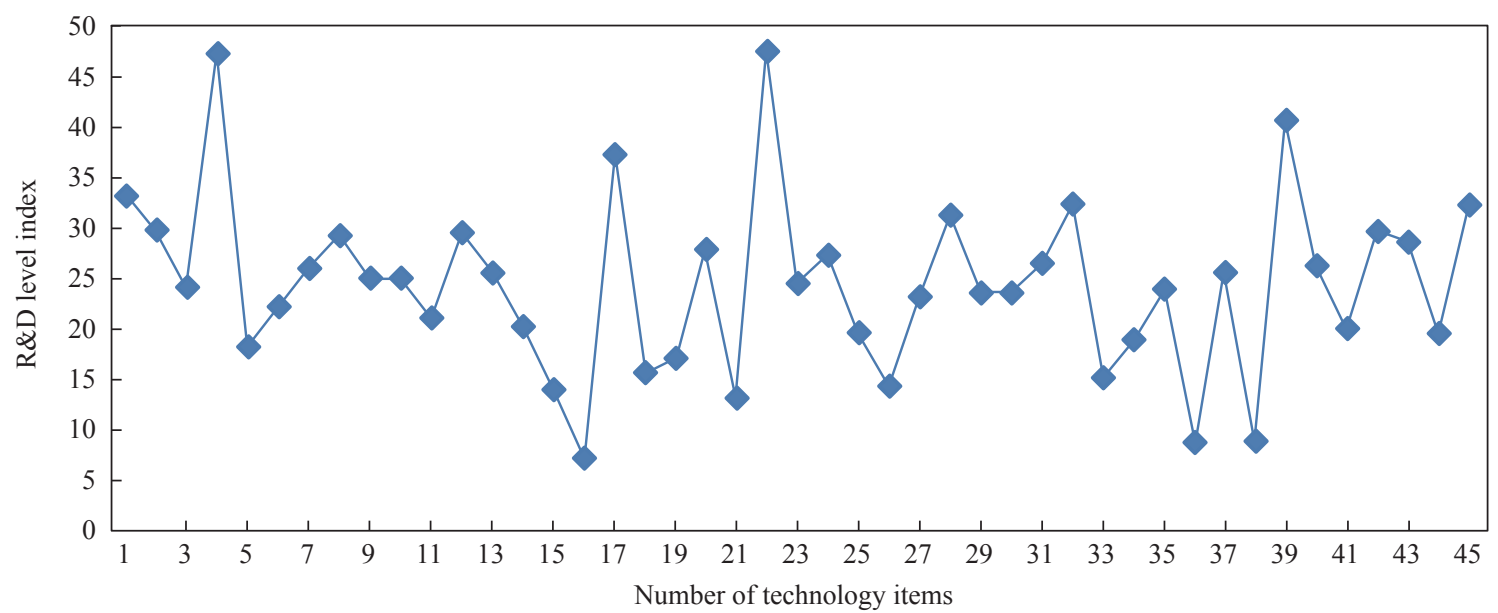

Fig. 5. R\&D level of technologies in this field. 
impact on the development of this field. R\&D investment exerts the greatest impact on the following five subfields: air pollution prevention and control; water pollution prevention and control; environmental monitoring, early warning, and risk control; soil pollution prevention and control; and resource utilization and cleaner production. Talents and science and technology resources have a greater impact on solid waste pollution prevention, control, and utilization, and on ecological protection and restoration. Restriction factors in the field of environmental engineering science and technology and its subfields are shown in Fig. 7.

\subsection{Analysis of technology realization time}

According to the survey results, in the field of environmental engineering science and technology, the technology realization time of China and of the world basically shows a normal distribution (Fig. 8). China's average technological realization will occur in 2025 or so, and the world's average technological realization will be in 2020 or so, with the former lagging behind the latter, according to the findings. In this respect, China's technologies will largely be realized in 2024-2027, and those that are

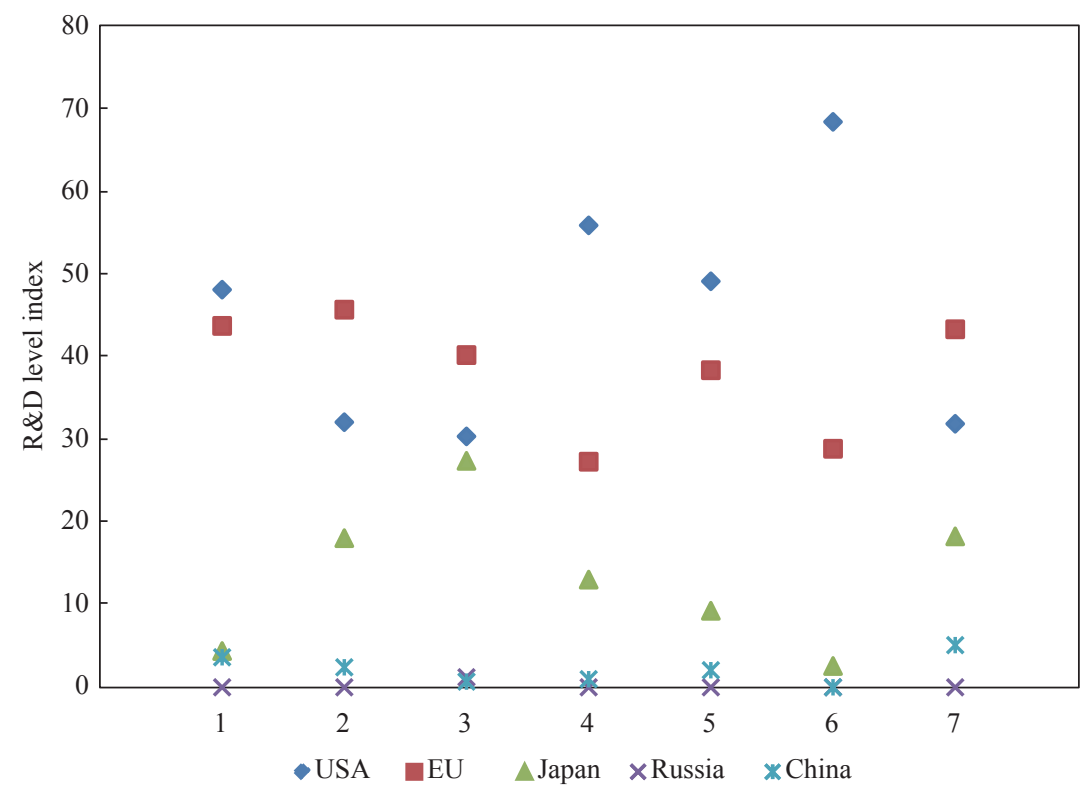

Fig. 6. Distribution of technological leaders in the field of environmental engineering science and technology.

Talents, science and technology resources (\%)

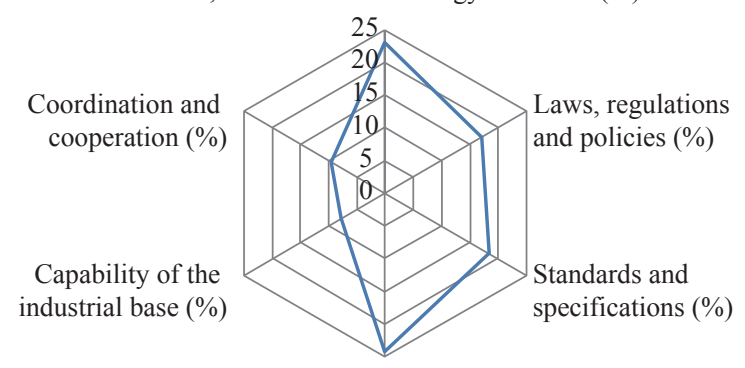

R\&D investment (\%)

- The field of environmental engineering science and technology
Talents, science and technology resources (\%)

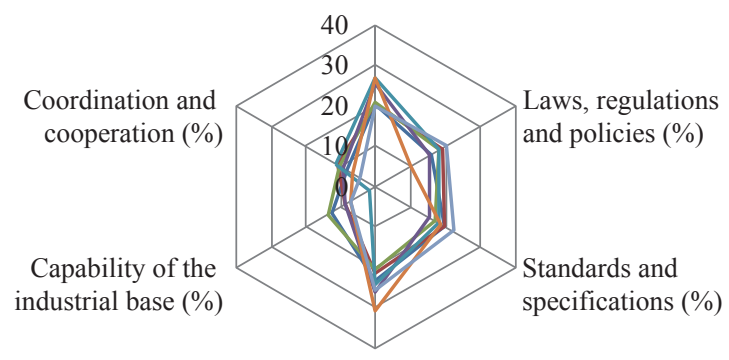

R\&D investment (\%)

(a)

\begin{abstract}
- Air pollution prevention and control
- Water pollution prevention and control

- Solid waste pollution prevention, control, and utilization

- Soil pollution prevention and control

- Ecological protection and restoration

— Environmental monitoring, early warning, and risk control

— Resource utilization and cleaner production
\end{abstract}

(b)

Fig. 7. Restriction factors in the subfields of environmental engineering science and technology. (a) Overall restriction factors; (b) Restriction factors in subfields. 


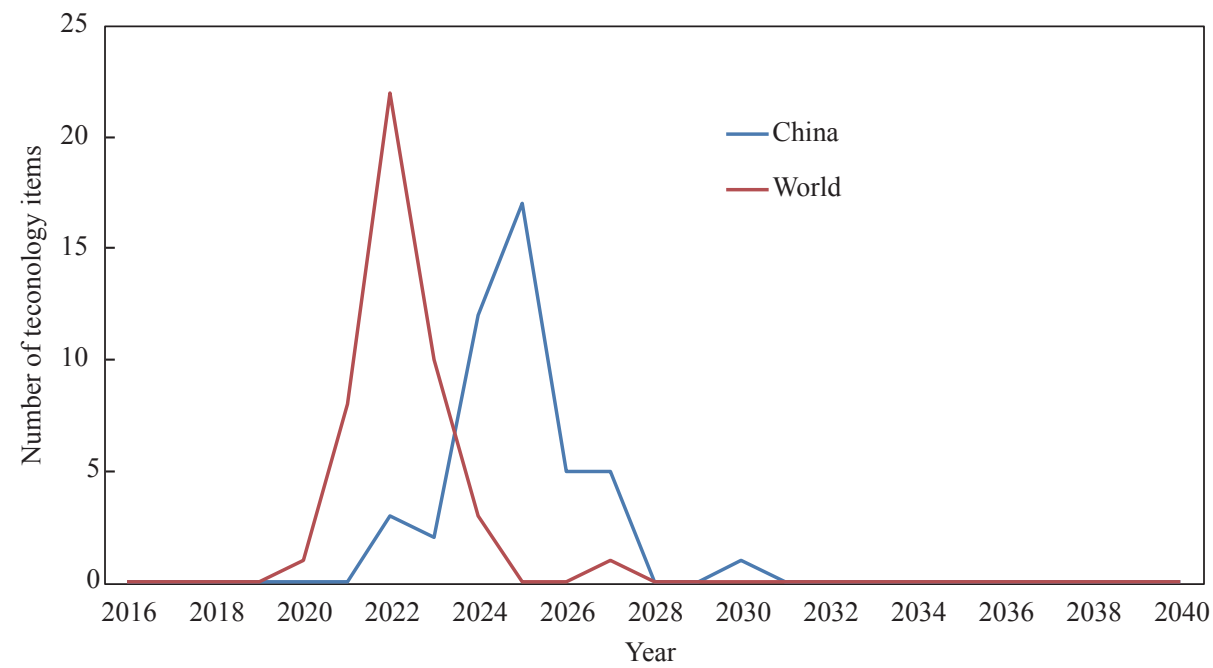

Fig. 8. Comparative analysis of technology realization time between China and the world.

realized in this period will constitute $86.7 \%$ of all technologies in this field; the world's technologies will mainly be realized before 2024, and those before that year will account for $99.8 \%$ of technologies in this field. While China has a lower technology R\&D level in environmental engineering, this country is more optimistic about the technology realization time.

\section{Conclusions}

This study conducted a Delphi survey on 45 alternative technologies in seven subfields of environmental engineering science and technology: air pollution prevention and control; water pollution prevention and control; solid waste pollution prevention, control, and utilization; soil pollution prevention and control; ecological protection and restoration; environmental monitoring, early warning, and risk control; and resource utilization and cleaner production. The results of the survey show the following:

(1) The key, common, and disruptive technology indexes among the alternative technologies of environmental engineering science and technology are, on average, 71.0, 51.5, and 37.8, respectively. The top-10 key technologies that cover all seven subfields are well represented and show the direction in which the field of environmental engineering science and technology is headed.

(2) The average R\&D level of environmental engineering science and technology is only 24.4, indicating a lower overall R\&D level. About $95.6 \%$ of technologies in this field remain underdeveloped or fall behind the world's corresponding level; the USA and EU maintain the leading position in this field's technol- ogy. R\&D in environmental engineering technology is primarily restricted by inadequate $R \& D$ investment and secondarily by a dearth of talent and science and technology resources.

The results of this study, which are proposed on the basis of the Delphi findings, only reflect the trend of the survey data. Because of the limitations of the survey method and the unpredictability of technology foresight, key, common, and disruptive technologies of environmental engineering science and technology need to be determined through a comprehensive study that combines the Delphi findings and the judgment of experts from various fields.

\section{References}

[1] Ben R M. Matching social needs and technological capabilities: Research foresight and the implications for social sciences (paper presented at the OECD workshop on social sciences and innovation) [Z]. Tokyo: United Nations University, 2000.

[2] Yuan Z B, Mu R P, Chen F. Foresight research on resource and environmental technology of the future 20 years in China [J]. Chinese Journal of Population Resources and Environment, 2008, 18 (6): 157-161. Chinese

[3] Research Group for Foresight Research on Technology of Future 20 Years in China. Foresight research on technology of the future 20 years in China [M]. Beijing: China Science Publishing \& Media Ltd., 2008. Chinese.

[4] Chen D M, Shen Q. Introduction of scientific and technological assessment and prediction [M]. Hefei: Anhui Science \& Technology Publishing House, 1996. Chinese.

[5] Linstone H A, Turoff M. The Delphi method-techniques and applications [M]. New York: Addison-Wesley, 2001. 